\title{
The classics, African literature, and the critics
}

\author{
Roger Field
}

\begin{abstract}
:
Faced with the criticism that myth and epic poetry have no place in contemporary South African literature departments, there is no point in defending the material on the grounds of intrinsic worth. No text can claim this privilege. Instead, students and lecturers alike may find value and relevance for these works if they explore a range of aesthetic, conceptual, cultural, and political issues that close readings may precipitate. After analysing a fictional demonstration of how not to teach The Odyssey, the article surveys a range of writers and cultural critics who identify as African or African-American, and whose work comments directly and indirectly on the history of the meaning, purpose and value of selected ancient and classical Greek texts. This spectrum stretches from defensive cultural nationalism to an open-ended combination of the cosmopolitan and the vernacular. The article concludes that a combination of resistance and appropriation is the best way to make new and local these canonical texts.
\end{abstract}

Mikey thinks back to the debate they had in class a few days ago. 'Homer's Odyssey is the basis of the modern novel,' Miss Anderson had said, looking expectantly at her students.

'Well, I think so,' she'd added, when she saw the indifferent expressions on their faces ...

'Well, Mr Ali, what do you think of Homer's Odyssey?'

'It is clichéd,' Mikey answers.

Give her the poker-faced treatment, sometimes it forces her to direct her venom elsewhere.

'Really?'

'Really.'

'Example?'

"'The pink fingers of dawn." Imagine the sun rising like that?'

'A metaphor for its time.'

'Clichéd,' he insists.

'No, worse,' Karabo Nkosi says. 'Eurocentric.'

'For God's sake! It's set in Europe. It's about Europe.'

'But the Greeks are darkies like us,' Vinu says.

'Cliched, that's all,' Mikey says.

'Think about it, Miss Anderson: the pink fingers of dawn over Sandton!' Karabo says.

'Is that where you live?' Miss Anderson asks, looking at Mikey.

'Who me? I live in Berea.'

'The township in the suburbs, Miss Anderson, that's where Mikey lives.' 
'Still, Homer Eurocentric and clichéd?'

'Dawn would have to be a white woman, then, with pink fingers, is that not Eurocentric?' Karabo asks triumphantly. He has Miss Anderson's measure, he thinks.

'Do you have pink fingers, Miss Anderson, can we see your fingers?' Vinu asks, her fervour false. Surely Miss Anderson must see the mockery of it all.

(Dangor 28-29)

Achmat Dangor's exchange mocks discourses of modernity and political relevance, and pits caricatured Euro- and Afrocentrisms against each other. ${ }^{1}$ Satire absolves Dangor from the obligation to offer constructive alternatives, but the question of appropriate content and pedagogy for postapartheid, postcolonial, postnational and postfallist $^{2}$ literature departments remains, and I return to this passage from Bitter Fruit often because it speaks to a range of issues generated by the University of the Western Cape's English II Literature and Myth course. The course features The Odyssey along with selections from the BleekLloyd collection and Ovid's Metamorphoses, fiction and poetry by Achmat Dangor, Greek Modernists, the twelfth-century Persian poet Nizami's The Story of Layla and Majnun, and films with mythological content and allusion. Dangor enables me to initiate conversations about matters such as myth and mythology, the description of "primitive" societies and historical consciousness; cultural capital, cultural nationalism, and race; cosmopolitanism and what Gadamer in Truth and Method calls "the classical" as an "historical stylistic concept" (256). It also provides an easily recognisable set of worst practices to avoid when teaching this material, which I can share with students. A better teacher, I like to think, would not have allowed the debate to become personal. When confronted with the criticism of "cliché," perhaps a responsive teacher would have pointed to The Iliad's and Odyssey's origins in orature, and proceeded, with the support of Isidore Okpewho's The Epic in Africa: Towards a Poetics of the Oral Performance (94-95, 216-17), to highlight similarities between, for instance, The Odyssey and the Sundiata epic. The latter is part of our Humanities interdisciplinary first-year course. This teacher might also have highlighted the phenomenon of Hellenism, and the many postcolonial appropriations such as Derek Walcott's Omeros, Pepetela's The Return of the Water Spirit, plays by West African dramatists that draw on Greek mythology, and the work of contemporary metropolitan classicists who explore the implications of these acts of "writing back."

This lecturer might also have responded to Vinu's retort that "the Greeks are darkies like us" by calling her bluff: recognising her combination of irony and political correctness, and allowing the interrogation to emerge through debate and discussion about whiteness, Greece, modernisation and modernity, encouraging her to read Abiola Irele's essay "In Praise of Alienation." lrele asks about the relationship between classical Greece and European modernity, and wonders "whether the ancient Greeks can be considered Europeans in the modern sense of the word" (221). Valentin Mudimbe's "The Power of the Greek Paradigm," Patrice Rankine's study of Ralph Ellison, Ulysses in Black: Ralph Ellison, Classicism, and African American Literature, and Richard Whitaker's The Iliad: A Southern African Translation might also be useful here. 
Each of these responses and suggestions has its challenges, and by examining these and other works, I hope we will be better placed to understand the relationship between Ancient and Classical Greek texts and African literary and cultural criticism, and how in the process of teaching these texts, lecturers and students may benefit from such exchanges.

In "The Relevance of African Cosmological Systems to African Literature Today," Mazisi Kunene criticises African writers who disparage "African cosmological concepts" and, with the partial exception of Soyinka, "derive maximum intensity for their creative ideas" from Judaeo-Greek mythology (190). Though he does not say how, modern African writers who aspire to produce "authentic African classics" should shake off the assumption that their indigenous literary heritage cannot provide appropriate models. Instead, they should acquire thorough knowledge of "the ancient stories" and the fundamental truths that have shaped them. These "ancient stories" are myths which display the following features: they confirm "fundamental social laws" (193), are "serious, embracing in different gradations all aspects of human life" (195), they are less concerned with chronology and causality, and more focused on "the place of man in the universe and his relationship with the supernatural powers" (197). Anyone who has read them could recognise this as a description of The Iliad or Odyssey, and C. S. Lewis's distinction between "primary" and "secondary" epics (267-68). It would be easy to dismiss Kunene's argument on the grounds that his cultural nationalism is deeply indebted to Lewis's Christian traditionalism, and that he advocates African authenticity by using the characteristics of that which he opposes - but therein lies a challenge which many in the Humanities may recognise: how to produce new knowledge and foster critical debate through the discourses bequeathed or imposed by the metropole, and whether or in what ways vernacular resistance to the West and its cultural appropriation are compatible (Pollock 47).

Okpewho's goal in The Epic in Africa is to "inquire into the aesthetic world of traditional art" so that he can establish "the logic of an independent poetics of performance" $(13,33)$. He is less concerned with whether, for instance, Sundiata has a greater claim to authenticity, or is closer to a putative first performance, than The Iliad. He assumes that the epic as genre consists of pre-existing formal and structural properties. Logically, therefore, the fact that The Odyssey has become the source of judgement for subsequent African works that share its properties is an accident of history, and not proof of its innate superiority. Since his focus is the African epic, he begins with this material and provides "comparative illustrations from the Homeric, Slavic, and other worlds" (The Epic in Africa 30). In principle, this promotes an even-handed approach, one which Pollock thinks is easier to achieve in practice than in theory (47). Alternatively, unless one whole-heartedly believes in literary or generic archetypes, it is hard to dispel the assumption that, like Kunene, Okpewho derives the very notion of epic and the categories he uses from those "other worlds." From that perspective, Karabo Nkosi's objection to studying The Odyssey makes sense, because in Miss Anderson's hands its imagery and imaginary set up Europe as the source of cultural and aesthetic value, but only if one does not question why race and place determine "the classical" or place it off limits.

\section{http://repository.uwc.ac.za}


Soyinka acknowledges these problems when he compares ritual theatre in Nigeria and Greek classical tragedies by Aeschylus and Euripides in Myth, Literature and the African World. Soyinka's premise is that a "race, a culture" can only truly know itself after it has assessed or compared itself against another expression of "collective awareness." Therefore, the project of African cultural liberation must rely on "external reference points against which a progression in thinking can be measured" (viii), but without accepting as universally true the prescriptions or underlying neuroses of metropolitan theory (x). This too, is a feature of Okpewho's later writing on myth, in which he begins with a working definition by Jacob Grimm from 1835, refining it through the contributions of anthropologists, scholars of African orature, and his own fieldwork (Okpewho, "Rethinking Myth" 5).

Soyinka argues that the purpose of ritual theatre is to create a space that accommodates mimesis and "a manageable contraction of the cosmic envelope within which man [...] fearfully exists," and that Greek tragedy and its accompanying society of sixth- and fifthcentury BCE, which he believes stood in a sufficiently harmonious relationship to each other, provide enduring insights into that purpose $(4,10,12-13: \cdot 41)$. In turn, these insights are only possible because he finds sufficient similarities between the Greek and Yoruba pantheons: for instance, both "commit serious infractions against mortal well-being." While the former thrive on "lust, greed, sadism, megalomania" $(13,14)$-Toynbee describes them as "a war-band of superhumanly potent but characteristically disreputable barbarians" (11)-for Soyinka the Yoruba pantheon subscribes to "the morality of reparation" $(13,14)$. All this enables him to posit two relatively harmonious societies, so that the reader or viewer who is willing to think in a synthetic manner that embraces both will understand their similarities and differences:

The idealist bronze and terra-cotta of Ife which may tempt the comparison implicit in 'Apollonian' died at some now forgotten period, evidence only of the surface culture of courts and never again resurrected [ ... ]. The mutual tempering of illusion and will, necessary to an understanding of the Hellenic spirit, may mislead us, when we are faced with serenity Yoruba to the art, for much of it has a similarity in its aesthetic serenity to the plastic arts of the Hellenic. Yoruba traditional art is not ideational however, but 'essential.' It is not the idea (in religious arts) that is transmitted into wood or interpreted in music or movement, but a quintessence of inner being, a symbolic interaction of the many aspects of revelations (within a universal context) with their moral apprehension.

This reliance on the notion of a Greek whole also emerges in Soyinka's criticisms of Chinua Achebe and George Thomson.

Soyinka relies on the deeply embedded notion of a classical Greek society in which harmony between individual minds and the collective consciousness of the polis prevails, creating that guiding external reference point on which his argument depends. This was an axiom of much nineteenth-and twentieth-century European and North American classical studies. In the "Greek realm," says Hegel in The Philosophy of Right (1821), "the principle of personal individuality arises, though it is still not self-enclosed but kept in its ideal unity. The result is

\section{http://repository.uwc.ac.za}


that the whole is divided into a group of particular national minds; ultimate decision is ascribed not to the subjectivity of explicitly independent self-consciousness but to a power standing above and outside it" (221). For Soyinka, the dramatic corollary is the bond between mimesis and symbolism in ritual theatre and the religious beliefs on which that theatre relies (Myth, Literature 86). That is why Chinua Achebe's Arrow of God cannot "project a social vision": it is too rooted in mimesis (Soyinka 87). Nor do Achebe's gods follow the path laid out for Poseidon by Euripides in The Trojan Women. Surveying ruined Troy after the Greek triumph, Poseidon declares: "I am leaving Ilium, that famous town, and the altars that I love; for when drear desolation seizes on a town, the worship of the gods decays and tends to lose respect" (Euripides).

By contrast, says Soyinka, Achebe has constructed the world of Arrow of God through the "monotonous" accretion (Soyinka 88) of detail that stops when protagonists find themselves in a religious space, for instance, when Ezeulu enters Ulu's shrine. This is not, Soyinka believes, Achebe's way of safeguarding Ulu's "mystery" (88), but a lost opportunity to demonstrate "the awe and reverence due to the autochthonous" (88). In effect, Soyinka argues that the novel imposes an empirical "secular consciousness" (92), but he only does so by ignoring a vital issue at the heart of mythology, canon-formation, and the power which both presume. In The Iliad, Poseidon sided with the Greeks; recast by Euripides as Troy's supporter, whatever "awe and reverence" the god receives in The Trojan Women follows from his dramatic and political role. This does not mean that Euripides did not believe in the Greek gods. Rather, as Paul Veyne suggests, the literary and political elite of that time, and by implication Soyinka's too, subscribed to a range of partially compatible beliefs about their pantheon, and could juggle "different levels of meaning" through which a "rhetorical[ ... ] use of mythology emerged" (42-43). Here literary analysis and canon formation rest on the power to naturalise a particular form of "juggling" which privileges the epics of Homer.

Soyinka takes issue with the Marxist classicist George Thomson on several aspects attractive to socially conscious readers. In Aeschylus and Athens, Thomson regards that charged collective consciousness generated by the integrated "song and dance of the mimetic rite" as "the subconscious world of fantasy" (59), but for Soyinka it is the "primal reality" (33). If he criticises Thomson for not following his own observations to the logical conclusion that he (Soyinka) desires, it is because in this context he is unwilling to interpret the Greek material as a comment on contemporary Greek politics and society, preferring to see it as suprahistorical. In the case of The Odyssey, a more time-bound interpretation would recognise Odysseus's mercantile or colonial gaze as he describes the Cyclops Polyphemus's islands with their fertile soil, natural harbours, but no governance or technology; "craftsmen," comments Odysseus, could have transformed the island into a "colony" or "settlement," a point on which translators of The Odyssey such as Rieu and Lattimore, and postcolonial critics such as McKinsey all agree. In The Trojan Women, this would be Euripides's condemnation of Athens's brutal imperial agenda, in particular its democratically sanctioned practice against enemy and neutral towns of enslaving all women and girls, and killing all men and boys (Harrison 25; Toynbee 100-107). 
Soyinka's reading also suggests an underlying reluctance to engage with experiences of social contradiction and psychoanalysis. The conclusion to Aeschylus and Athens demonstrates that Thomson was acutely aware that where tragedy combines mimesis and symbolism, catharsis plays a socially ameliorative role:

katharsis, or purification [ ... ] renewed the vitality of the participants by relieving emotional stress due to the contradictions generated in the course of social change. And this purpose was achieved by the expression of what had been suppressed. The different forms which this function [of catharsis] assumed are explained by the increasing complexity of the social structure which rendered the mode of expression less violent.

Like psychoanalysis, catharsis assumes that "the individual must be adapted to society, not society to the individual." From Thomson's 1930s Marxist perspective, the tragedies of Aeschylus, and by implication Soyinka's ritual theatre, play a simultaneously conservative and subversive social role (359-60). It would be another 20 years before Fanon's The Wretched of the Earth would advance the contribution of indigenous myth to the anticolonial struggle. Like Thomson and Soyinka, he recognises that "myth and magic" simultaneously "frighten" and "integrate" "the native" into tribal or regional "traditions and ... history," creating a sense of collective identity and another 58 source of mobilisation. Against this "the settler's powers are infinitely shrunken, stamped with their alien origin." Like Thomson, and unlike Soyinka, Fanon believes that "the so-called prehistoric societies attach great importance to the unconscious" (43). Unlike Thomson, Fanon believes that it is possible to disconnect the concept and existence of the unconscious from Western, colonial modes of control, so that in the hands of an anti-colonial avant-garde it may contribute to political and cultural liberation.

For Abiola Irele, individual social alienation is fundamental to tragedy and modernity. Accordingly, he argues that Africa and its intellectuals have been trapped in a "passive" bad alienation, which Arrow of God interrogates. Where Soyinka criticises that novel for its realist, Western treatment of African religion and ritual, for lrele what makes Achebe's novel a tragic "masterpiece" is its "humane pessimism" (lrele 204) about the limits of individual and collective freedom in the face of unstoppable social forces. He regards cultural nationalism as a backward-looking response to this development, for the assertion of cultural continuity between precolonial and contemporary Africa is "a refusal of history" (206-207). Like the nineteenth-century European Hellenism which projected notions of an organic totality onto fifth-century Athens, African cultural nationalism is a self-consciousness that tries to deny its own self-consciousness; it evokes a past characterised by an unmediated pure presence and the monumental achievements of complex civilizations, and refuses to acknowledge that "traditional cultures are simply not adequate for our [modern African] needs and interests" (213-14). The real failure of African intellectuals is not Europe's "cultural hold," or their inability to transcend a "divided consciousness" (202, 203), but their failure to transform that alienation into a desire to act on the world positively. In turn this desire requires that African intellectuals must want to discard that comfortable "self-

\section{http://repository.uwc.ac.za}


consciousness that goes with cultural nationalism," in order to desire "new horizons of life and experience" (214-15). Echoing Jürgen Habermas's "Modernity: An Unfinished Project," the way to do this, says Irele, is to observe how ancient Greece created a "viable society" (223) by resolving the contradiction between mythopoetic and deductive modes of thinking during a period of radical social and political change; in tum this created the conditions for a "conceptual breakthrough" that made possible a modem world founded on science and technology (Irele 223; Dihle 96-99), and which has given the West a massive advantage over Africa.

The fact that this became the West's developmental autobiography and model for Western colonialism and imperialism (47) does not mean, Irele reminds us, that the Greeks were European "in the modern sense of the word" (221 ), or that they were free from outside influence. The debate about who or what "the Greeks" were, how Greece became the foundation of Western civilization, and whether they were transformed into Western and Northern Europeans inevitably reverts to Martin Bernal, whose work has received more support from those outside the discipline of Classics than among classicists. In Black Athena: The Afroasiatic Roots of Classical Civilization he distinguishes between two explanatory histories of the origins of ancient and classical Greece, the Aryan and Revised Ancient Models. The Aryan Model claims that "Greek civilization was the result of cultural mixture flowing from the north by Indo-European-speaking Greeks of the earlier "PreHellenic peoples," largely untouched or unsullied by people or cultures from Africa and the Levant. The Revised Ancient Model stresses the contribution of Levantine and North African cultures to the development of Greece. For Bernal, proponents of the Aryan model rely less on historical and archaeological data than on the claim that their "scientific" and "critical" methodology renders their findings superior to the contemporary yet more "credulous" Classical and Hellenistic writers (Black Athena Vol. II, 9; Black Athena Vol. I, 325-26). Bernal also remarks that "most of the men who established the Aryan model were... to put it bluntly -racists and anti-Semites" (Black Athena Vol. I, 303- 304).

Valentin Mudimbe takes up this argument in "The Power of the Greek Paradigm" when he observes that whether we like it or not, Bernal's enterprise will profoundly mark the next century's perceptions of the origins of Greek civilization and the role of ancient Egypt. Indeed, his project witnesses to a reversal of what made possible and founded the slave trade since the fifteenth century: imperialism and colonialism, with their triumph in the nineteenth century, so well exemplified in the 1930 s and 1940 s by Nazism, their natural product.

(104)

Here he has in mind Nazi genocide and its art. Much of the latter was modelled on Greek sculpture and architecture, used Greek mythology as its subject matter, and drew a direct genealogical and cultural line between the "Aryan race" and classical Greece (Michaud, The Cult of Art 130, 138, 142, 152). Mudimbe is also able to trace what he describes as "a wellspecified geography of monstrosity" ("The Power" 78) partially located in Africa, in which geographical and cultural proximity to Greece became the standard of civilisation (89). For

\section{http://repository.uwc.ac.za}


Malvern van Wyk Smith (The First Ethiopians 67), however, the situation is more complex, and not automatically indicative of racism. He notes two types of Ethiopians in Homer: in Book I of The Iliad they are "blameless" (trans. Lattimore), or "noble" (trans. Whitaker); in Book I of The Odyssey they are the "most distant of men, who live divided,/ some at the setting of Hyperion, some at his rising" (trans. Lattimore), or "distant [ ... ] in the most remote part of the world, half of whom live where the Sun goes down, and half where he rises" (trans. Rieu). In both books, they host Poseidon and treat him to a sumptuous feast.

Mudimbe and Rankine share several criticisms of Bernal's work. Both point out that the Aryan Model was not as monolithic as he suggests, that contemporary writers did not refer to Phoenicia and Egypt as consistently or as frequently as he implies, that he attributes equal value to qualitatively different sources such as mythology and archaeology in his arguments about origins, and that he uses "race" to attract attention to his argument, sometimes in ironic ways (Rankine, Ulysses in Black 71-74; Mudimbe "The Power" 93-95). Bernal acknowledges that his thesis "would not have enjoyed even a first hearing" had he not been "white, male, middle-aged, and middle-class but also British in America," and that these features have provided him with "a tone of universality and authority that is completely spurious" (Bernal, qtd. in Mudimbe 103). This stands in contrast to the Afrocentrist histories of the Greek contribution to Western civilization that Van Wyk Smith so strongly attacks (8687). Bernal's and Mudimbe's point - that methods of enquiry and reconstruction in the Humanities can never be politically neutral - returns us to the question which Kunene's approach raised: how to produce new knowledge and foster critical debate through the discourses and referential frameworks bequeathed or imposed by the metropole. Both agree that whiteness, if not "race," is a social construct which significantly affects the currency of knowledge.

In Ulysses in Black, Patrice Rankine describes Bernal's main claim as "heretical," but also acknowledges its political significance. In North America, its publication was "a watershed moment in the relationship between the classics and race discourse," making it possible to question the assumption that "a black classicist is a curious and suspicious paradox (similar to the paradox that, for example, a white rapper might represent)" $(23,30)$. Toni Morrison has joined this debate. Echoing aspects of Okpewho and Soyinka's contributions, in Unspeakable Things Unspoken: The Afro-American Presence in American Literature she says that a "large part of the satisfaction I have always received from reading Greek tragedy, for example, is in its similarity to Afro-American communal structures (the function of song and chorus, the heroic struggle between the claims of community and individual hubris) and African religion and philosophy" (125). For Morrison, who champions a more demographically representative American literary canon, the value chain is clear: Greek tragedy is accessible and pleasing because it is like an already-established social order with its own independent, non-Western history that she prioritises, and with which she identifies. This makes it easier to claim the pleasure of the classics.

At issue in these divisions between Aryan and Revised Ancient Models, and between Europe on the one hand, and Africa and the Orient on the other, are matters such as racial, cultural,

\section{http://repository.uwc.ac.za}


and linguistic authority and purity. This must also affect, as Soyinka's Myth, Literature and the African World implies, how one translates, adapts and teaches the classics and mythology in a South African context. In both cases, what the putative Homeric and African worlds share, which common elements are important, and how one demonstrates commonality, are all open to debate. Andrea Doyle feels that in Richard Whitaker's translation of The Iliad, "[t]he weaponry and armour described in Homer's Iliad is not consonant with that of a Zulu impi" (emphasis in original). Thus Whitaker's plot summary refers only to assegais and spears; in the text itself, for instance in Book 22, references to "sharp bronze," "long spear" and "bronze-weighted spear" and swords sit uneasily with "long assegai" and "bronze-barbed assegai" (Doyle).

In the introduction to his translation, Whitaker acknowledges the dangers of "pastiche," which the use of several languages may create, and after Jameson it is difficult to erase its negative associations. In response, he argues that for many South Africans code-switching is an everyday practice, and that no language is pure, not even Homer's Greek. Whitaker believes that using a variety of languages helps to "dignify the colloquial" ("Introduction" 54), though he never fully explains why this is necessary. Southern African English already includes words which describe a transaction involving cattle that accompanies marriage, and this was a common practice at the time of The Iliad's composition (55); the epic draws attention to the fact that Kabesos "had asked/Priam for the hand of [ ... ] Kassandra, without bride price, but had promised a great work for her" (Homer trans. Lattimore 281 ). One aim of translation might be to render itself invisible, but translation is also an opportunity to alienate the "Western" reader (Whitaker, "Introduction" 54) by evoking associations between Africa and ancient Greece. Terms such as "assegai" and "impi" do not prove Vinu's point that "the Greeks are darkies like us," but they may mitigate the tendency to see the Homeric and classical worlds as both "other" and imperialist fellow travellers.

Whitaker's search for cultural commonalities through translation also aims to offset the perceived lack of Western cultural capital which students may face when reading Homer the Cultural Deficit Model. At times the appeal to African orature encounters a similar objection. Discussing its features may help to explain the repetition of epithets such as "the pink fingers of dawn," and why Mikey's criticism of "clichéd" is misguided. However, even if students accept that explanation, they may not want to recover or imagine a precolonial past. A student might regard this as anti-modern, racist paternalism: when black African students see that elements of "their" cultural world are like Homer's or Sophocles's, whether it is lobola or veneration of ancestors, "they" will understand the latter more easily.

From Whitaker's perspective, there is an equally compelling and complicating counterargument drawn from his remarks about the history of Iliad translations, and it supports Bernal's criticisms of the Aryan model. In defence of his decision to use words such as "amakhosi," "induna" and "inkosi" to designate the social and political organisation of the forces besieging Troy, Whitaker comments: "It is interesting to note that several English translators of the eighteenth to mid-nineteenth century used "chief," among other terms, to refer to the leaders of the Akhaians [Greeks]. One wonders what scruples have kept more 
recent translators from doing likewise" ("Introduction" 59). Since the consolidation of the Aryan Model coincides with the rise of colonialism and imperialism, a term such as "chief," which suggests a relatively primitive social organisation not unlike the indigenous societies in the colonies, would be an inappropriate designation for the rulers of the heroes who laid the foundations for Western artistic, philosophical, intellectual, technical and political superiority.

Returning to Miss Anderson and her "spoiled, post-apartheid hedonists" (Dangor 27), Vinu's project is simple: to relocate "the Greeks" from Miss Anderson's Europe to the Global South. In the process, Vinu alludes to situations in which there is a hierarchy of dominant cultures. As Mudimbe points out, to be civilized was to be Greek or, later, Roman: "Acculturation meant, in practice, a radical conversion to the Greek or Roman model of life. Its implications included abandoning one's original language and becoming a member of the Greek or Roman politeia, and, if possible, acquiring rights of citizenship in the polis or urbs. Only such a conversion could bestow on people the virtues of gentleness (emeron) and civility (politikon)" ("The Power" 90-91). Toynbee views this less critically as a relatively benign or soft cosmopolitanism. In Hellenism: The History of a Civilization, he specifies Hellenism's key features. It was "a distinctive way of life which was embodied in a master-institution, city-states; and anyone who acclimatized himself [sic] to life as it was lived in an Hellenic city-state would be accepted as a Hellene, no matter what his background might have been" (6); it was "the most whole-hearted and uncompromising' practice of man-worship [Humanism] that is on record up to date" (8). That Alexander the Great's conquests established Hellenism, and that it lived on through the Roman Empire demonstrates that it was not as benign as Toynbee imagines. It was an elite way of life that benefitted from an environment of "political unity and internal peace [ ... ] under a single government," and could spread through the use of Latin and/or Greek, for the two enjoyed "official parity," though Latin was the empire's official language (Toynbee 3-4: Dihle, A History of Greek Literature 231-35).

Mudimbe, Toynbee and Dihle point to situations in which a political ideology, language and religion that originated in a lesser power (Greece) became part of a greater one, and a fellow traveller closely associated with empire but without its "burden" of state. In these circumstances, the place and language of civilisation may not be amenable to simple Manichean oppositions, as Mudimbe's shifts between Greek and Latin terms such as polis and urbs to refer to civic and political culture and organisation suggest.

Poems by Constantin Cavafy such as "Trojans," "The Horses of Achilles," "Philhellene" and "Myres: Alexandria, AD 340" might offer students some insight into the shifting fortunes of Greece, Greek and Hellenism. Read in this sequence, they chart a transition from the world of epic and myth, to comprador Hellenic snobbery under Roman rule, to the suppression of pagan religion and same-sex desire by an ascendant Christianity. By analysing these poems, students may encounter other perspectives on the experience of retaining or losing one's own beliefs and values within a more dominant culture. As elaborations of events in The Iliad, "The Horses of Achilles" and "Trojans" (22-23, 40-41) take the dominance of ancient and

\section{http://repository.uwc.ac.za}


classical Greek culture and power for granted: gods, immortal animals, and heroes know their places, and behave in accordance with the story.

In "Philhellene," a Parthian king under Roman rule who lives on the north-eastern edge of the Hellenic world expects a visit from the prying Roman proconsul. The king speaks to his jeweller and engraver about his diadem. It should not be in the local Parthian style; rather, it should carry a Greek inscription and "the image of some handsome youth, a discus-thrower," in order to demonstrate that "we are not lacking in Greek culture." But he cautions the engraver to keep the lettering discreet "lest the proconsul, who always pokes around/and reports to Rome, take it the wrong way" (Cavafy 54-55). Exercising a Du Boisian "double consciousness," this king knows that he has to police himself sexually and culturally. He may express some autonomy through philhellenism, provided that he correctly anticipates the official's responses. "Myres: Alexandria, AD 340" shows how two Greek religious, cultural and sexual ways of being-in-the-world - one pagan and sensual, the other Christian and rulebound - are ultimately incompatible. The speaker, an openly pagan and sensual homosexual, mourns the death of his dear companion Myres. Two factors make him feel alienated in Myres's Christian home. One is the emphasis on detailed observance of ritual, and the stress. on demonstrations of faith (191). The other emerges when the speaker realises that some of Myres's participation in his world was mimicry, for instance his "perfect sense of Greek rhythm" (189). This fall from pre-eminence may remind students that "awareness of decline and distance [...] gives birth to the classical norm" (Gadamer, Truth and Method 256), and therefore enable them to understand why and how the power and status of cultural canons and ways of being-in-the world may change, and may be taken up in many different ways. From this it follows that Cavafy's poems can achieve this, because the classics, Greek mythology and Hellenism have gathered a momentum, and continue to make their presence felt through numerous appropriations and reworkings. For students of African literature, the myth of Orpheus and Eurydice re-appears in "Black Orpheus," Sartre's 1947 introductory essay to an anthology of negritude poetry, a 1959 film set in Brazil, and the title of a Nigeriabased cultural journal co-edited by Es'kia Mphahlele and Soyinka between 1960 and 1964 . All of these undergo what Martin McKinsey in Hellenism and the Postcolonial Imagination calls an "inevitable transvaluation" when canonical texts and literary figures, often with a long history of interpretation within a colonial and imperial power, find their way to the colonies, initially to valorise those colonial and imperial projects. In these new settings, such texts and literary entities do not "'mean' in the same way" (24). By "inevitable," he refers to the reworking that must accompany the transference of mythology from one context to another. Transvaluation also implies a form of double consciousness in which the writer transfers Western cultural capital acquired in youth or adolescence to her adult, more analytical and politically critical self. Like McKinsey, Phiroze Vasunia is fully aware that any analogy between, for instance, British and Roman empires or between Greek myth and prevailing socio-political conditions in a colony or postcolony, follows from "immense pressure [...] generated by social, cultural, and political forces to render natural and immediate" the comparison (57).

\section{http://repository.uwc.ac.za}


One example of this pressure at work is the 1835 "Macaulay Minute." To support his argument for the extension of British education in India at the expense of local knowledge, Lord Macaulay advocated forced modernisation modelled on the contribution of the classics to the acceleration of European intellectual and material progress during the Renaissance:

At that [Renaissance) time almost everything that was worth reading was contained in the writings of the ancient Greeks and Romans. Had our [English) ancestors acted as the Committee of Public Instruction has hitherto noted, had they neglected the language of Thucydides and Plato, and the language of Cicero and Tacitus, had they confined their attention to the old dialects of our own island, had they printed nothing and taught nothing at the universities but chronicles in Anglo-Saxon and romances in Norman French, -would England ever have been what she now is? What the Greek and Latin were to the contemporaries of More and Ascham, our tongue is to the people of India.

(Macaulay)

As Greek and Latin were to Anglo-Saxon and Norman French, so English and the ideas conveyed through it should be to the elite subjects of India in order to create "a class who may be interpreters between us and the millions whom we [British] govern, -a class of persons Indian in blood and colour, but English in tastes, in opinions, in morals and in intellect" (Macaulay). That Englishness included the classics.

By the mid-nineteenth century the classics in general had become an integral part of British elite education (Bernal, Black Athena I 320,324). For the upper ranks of the Indian Civil Service, knowledge of Greek and Latin was "almost indispensable," and according to Vasunia candidates for its entrance examinations could expect questions such as "What lessons with regard to the principles which should be observed in the government of British India may be learned from the history of the Roman dominions under the Republic and the Empire?" (43). In Arrow of God, Achebe makes the same point about British colonial administration in Nigeria through a fictitious colonial memoir, The Pacification of the Primitive Tribes of the Lower Niger. He "quotes" from a chapter titled "THE CALL": "Is it only for the desk our youngsters read of Drake and Frobisher [ ... ]? Is it for the counting house they learn of Carthage, Greece and Rome? No, no; a thousand times no!" (32-33). Here the continuity between Achebe's and Cavafy's outlying administrators is instructive: both hold on to Greece as a symbol of cultural superiority; for the former it rationalises power; for the latter it seeks compromise once political power has been lost.

McKinsey's view of the significance of The Iliad and The Odyssey for nineteenth-century British imperial ideology makes a similar point. The former, "with its tale of a punitive expedition against a troublesome oriental regime, resonated with contemporary events" (36). Tennyson's poem "Ulysses" may be one of several expressions of mourning for Arthur Hallam, but it sustains another interpretation with at least three mutually supporting elements: the settler-colonial assumption that the territory currently beyond imperial knowledge is by definition uninhabited or under-utilised; the elite's obligation to civilise primitive peoples; the frustrations of a retired or returning colonial administrator and "man

\section{http://repository.uwc.ac.za}


of action" who cannot settle down at "home" (40-47). Much the same applies to French and Portuguese imperial ideology and expressions of anticolonial resistance such as The Wretched of the Earth. "The wealth of the imperial countries," says Fanon, "is our wealth too." However, he actively distances the national revolution from the farmer's artistic influence or "riches," for "[o]n the universal plane this affirmation, you may be sure, should on no account be taken to signify that we feel ourselves affected by the creations of Western arts or techniques" (81 ). Rather, the "great figures of the colonized people" are those like Sundiata "who led the national resistance to invasion" (54), and through whom "the old warrior-like traditions spring up again" (92). Fanon affirms an indigenous tradition of cultural resistance, and criticises the "native intellectual's" deeply-rooted defence of "the Graeco-Latin pedestal" (36). He shares with Amilcar Cabral's "National Liberation and Culture" confidence in a "backward surge of intellectuals towards [cultural] bases grounded in the people" (Fanon 36).

However, neither Fanon nor Sartre, in his introductory remarks to Black Orpheus or in his Preface to The Wretched of the Earth, in which he compares purifying and healing violence to the "lance" of Achilles (25), dispenses with the myths of ancient Greece. These simultaneously pressure them, in Vasunia's sense, and enable them to talk back to the metropole in its own language - the discourse of power and the classics. Within or beneath Sartre's desire to turn the coloniser's culture into the oppressed's weapons, and Fanon's ironic description of the settler's contribution - "[t]he settler makes history; his life is an epoch, an Odyssey" (39) - lies the power of the Greek paradigm. To read irony or sarcasm in Fanon's references to "Aristotlean logic" (30), the colonial bourgeoisie's "narcissistic dialogue" (36), "the native's" automatically presumed guilt as a "sword of Damocles" (41), or Fanon's oedipal interpretation of anticolonial resistance is to acknowledge an earlier, presumed innocent encounter with the mythology and the cultural values of empire. These would include the continued, shared, silent pleasure that unites conservative metropolitan, comprador "native" and colonial insurgent intellectuals in their joint recognition and appreciation of these classical allusions. This is why Cabral advocates "re-Africanization" (emphasis in original 145), for it fertilises the seed of resistance which grows into the national liberation movement (143).

Within Anglophone postcolonial literature, the Caribbean and West Africa have generated the majority of mythological transvaluations. There Britain set up universities that taught Latin and Greek - educational policy in African colonies with established minority settler societies such as South Africa and Rhodesia differed- and several of the West African playwrights whose works draw on Greek tragedians such as Soyinka and Efua Sutherland (Euripides), J.P. Clark Bekederemo and Femi Osofisan (Aeschylus), and Ola Rotimi (Sophocles) benefitted from colonial education, and studied at British and American universities, some with a classical tradition (Budelman 121, 119). We have already seen that for Okpewho, Soyinka or Morrison there is no question that in principle Greek and African epic and drama are not equal, and that Soyinka's stress on expediency, treating the former as one way of understanding the latter while declaring that he has not made any concessions to it, and creating "a space for building West African (or other) identities and literatures"

\section{http://repository.uwc.ac.za}


(Budelman 123), extricated him from some of the problems which Okpewho and Kunene face.

For Soyinka this created other problems, such as a reluctance to read Greek tragedy as a response to dramatic social change, or to acknowledge the possibility that Greek tragedians such as Euripides had a more complex relationship to the Greek pantheon than idealised notions of Attic harmony permit. In tracing these responses to the classical presence in Africa, North America and Europe and some of its former colonies, I have not addressed the question of whether these ancient and classical texts have intrinsic value, not only because my belief is that no text can make such a claim, but also because every single writer to whom I have referred treats them as a means to an end. I believe that the classics are good stories to tell, but like much, if not all, metropolitan literature, they carry the burden of powers, policies and ideologies that have unjustifiably asserted that they are the first and best stories to tell. Nevertheless, like all fiction, the classics contain ideas whose relevance and purchase change according to time, place and political agenda.

Bemal's reliance on a Kuhnian metanarrative contributes a compelling quality to his analysis, but it also means that if he criticises advocates of the Aryan Model for assuming that their superior methodology would guarantee a correct conclusion, the same objections must apply to his own work. On that basis, it should be possible to suggest to Karabo, who dismisses The Odyssey as "Eurocentric," that she replace the Aryan Model with Sheldon Pollock's assertion that the future of cultural politics should be "one of and rather than either/or," and that "the blunt refusal to choose" between opposites is productive (47, emphasis in original).

Fanon, like the West African playwrights already mentioned, was pressured and enabled to talk and write back to the colonial power in its own discourse through the signifiers of Greece, which these powers had appropriated and modified to reflect idealised images of themselves. The social effect or function of these postcolonial, postapartheid, postnational and postfallist encounters with myths, epics and tragedies upon which they rest have not remained constant since the times of Homer, Aeschylus and Euripides. Unlike Kunene, and like Soyinka, Irele, Rankine and Whitaker, Pollock's argument that resistance may occur through "appropriation" suggests that they need not and should not, provided that those who resist in this way know what and why they are appropriating, and do so on their own terms. As literature teachers, we return to the dual tasks: to challenge prevailing power relations and their ideological underpinnings, including our own, and to question how one might balance the cultural capital that enjoyment and understanding of Homer or Aeschylus requires against the need to affirm students' perceptions of their lived experiences, while encouraging them to interrogate both.

\section{http://repository.uwc.ac.za}


Notes

1. An Erasmus Mundus travelling fellowship in the Department of Greek Studies at the University of Leuven enabled me to complete this article.

2. $\quad$ By "post-" I mean after the beginning of that event, but never subsequently without it. 


\section{Works Cited}

Achebe, Chinua. Arrow of God. 1964. London: Heinemann, 1974.

Bernal, Martin. Black Athena: The Afroasiatic Roots of Classical Civilization. Vol I. New Brunswick: Rutgers UP, 1978.

-----Black Athena: The Afroasiatic Roots of Classical Civilization. Vol II. New Brunswick: Rutgers UP, 1991.

Budelman, Felix. "Greek Tragedies in West African Adaptations." Classics and Colonialism. Ed. Barbara Goff. London: Duckworth, 2005. 118-46.

Cabral, Amilcar. "National Liberation and Culture." Unity and Struggle: Speeches and Writings. Trans. Michael Wolfers. New York: Monthly Review Press, 1979. 138-54.

Cavafy, Constantin. C.P. Cavqfy: The Collected Poems. Trans. Evangelos Sachperoglou. Oxford: Oxford UP, 2008.

Dangor, Achmat. Bitter Fruit. Cape Town: Kwela, 2001.

Dihle, Albrecht. A History of Greek Literature from Homer to the Hellenistic Period. Trans. Clare Krojzl. London: Routledge, 1994.

Doyle, Andrea. "Iliad's African Odyssey." Mail \& Guardian, 10 January 2013. Web. 22 March 2013. <http://mg.co.za/article/2013-01-10-iliads-african-odyssey/>.

Euripides. The Trojan Women. Trans. Anon. The Internet Classics Archive. Web Atomic and Massachusetts Institute of Technology, 1994. Web. 13 Dec. 2014. $<$ http://classics.mit.edu/Euripides/troj_women.html >.

Fanon, Frantz. The Wretched of the Earth. 1961. Trans. Constance Farrington. Harmondsworth: Penguin, 1978.

Gadamer, Hans-Georg. Truth and Method. Trans. G. Barden and J. Cumming. New York: Crossroad, 1975.

Goff, Barbara. Introduction. Classics and Colonialism. Ed. Barbara Goff. London: Duckworth, 2005.

Habermas, Jilrgen. "Modernity: An Unfinished Project." Trans. Nicholas Walker. Habermas and the Unfinished Project of Modernity. Ed. Maurizio Passerin d'Entreves and Seyla Benhabib. Cambridge MA: Massachusetts Institute of Technology Press, 1979. 38-55.

Harrison, Thomas. "Through British Eyes: The Athenian Empire and Modern Historiography." Classics and Colonialism. Ed. Barbara Goff. London: Duckworth, 2005. 25-37.

Hegel, Georg Wilhelm Friedrich. Philosophy of Right. Trans. Thomas Malcolm Knox. New York: Oxford UP, 1973.

Homer. The Iliad. Trans. Richmond Lattimore. Chicago: U of Chicago P, 1961.

-----. The Iliad of Homer: A Southern African Translation. Trans. Richard Whitaker. Cape Town: New Voices, 2012.

-----. The Odyssey. Trans. Emile Victor Rieu. Oxford: Oxford UP, 2008.

-----. The Odyssey. Trans. Richmond Lattimore. New York. Harper Collins, 2009.

Irele, Abiola. "In Praise of Alienation." Surreptitious Speech: Presence Africaine and the Politics of Otherness, 1947-1987. Ed. Valentin Mudimbe. Chicago: U of Chicago P, 1992. 201-224.

Kuhn, Thomas. The Structure of Scientific Revolutions. Chicago: U of Chicago P, 1970. 
Kunene, Mazisi. "The Relevance of African Cosmological Systems to African Literature Today." African literature Today: Myth and History 11 (1980): 190-205.

Lewis, Clive Staples. "The Style of Secondary Epic and Defence of This Style." Milton Criticism: Selections from Four Centuries. Ed. James Thorpe. London: Routledge \& Kegan Paul, 1965. 267-88.

Macaulay, Thomas Babington. "Minute by the Hon'ble T. B. Macaulay, dated the 2nd February 1835." Bureau of Education. Selections from Educational Records, Part I (1781-1839). National Archives of India. 1965. Web. 20 Dec. 2014. <http://www.columbia.edu/itc/mealac/pritchett/OOgenerallinks/macaulay/txt_min ute_education_1835.html>.

McKinsey, Martin. Hellenism and the Postcolonial Imagination: Yeats, Cavqfy, Walcot. Cranbury NJ: Fairleigh Dickinson UP, 2010.

Michaud, Erich. The Cult of Art in Nazi Germany. Trans. Janet Lloyd. Stanford: Stanford UP, 2004.

Morrison, Toni. Unspeakable Things Unspoken: The Afro-American Presence in American $\begin{array}{llllll}\text { Literature. } & 1988 . & \text { Web } & 21 & \text { Dec. } & 2014 .\end{array}$ $<\mathrm{http}$ ://tannerlectures.utah.edu/_documents/a-to-z/m/morrison9o.pdf.>.

Mudimbe, Valentin. "The Power of the Greek Paradigm." The Idea of Africa. Oxford: James Currey, 2005. 71-104.

Nizami. The Story of Layla and Mqjnun. Trans. Rudolph Gelpke. New York: Omega, 2011. Okpewho, Isidore. The Epic in Africa: Towards a Poetics of the Oral Performance. New York: Columbia UP, 1979.

-----. "Rethinking Myth." African Literature Today: Myth and History 11 (1980): 5-23.

Pepetela. The Return of the Water Spirit. Trans. Luis R. Mitras. Oxford: Heinemann, 2002.

Pollock, Sheldon. "Cosmopolitan and Vernacular in History." Cosmopolitanism. Ed. Sheldon Pollock, Homi K. Bhabha, and Carol A. Breckenridge. Durham NC: Duke UP, 2002. 15-53.

Rankine, Patrice. Ulysses in Black: Ralph Ellison, Classicism, and African American Literature. Madison WI: U ofWisconsin P, 2006.

Sartre, Jean-Paul. Preface. The Wretched of the Earth. By Frantz Fanon. Trans. Constance Farrington. Harmondsworth: Penguin, 1978. 7-26.

Soyinka, Wole. Myth, Literature and the African World. Cambridge: Cambridge UP, 1979.

Thomson, George. Aeschylus and Athens: A Study in the Social Origins of Drama. London: Lawrence and Wishart, 1973.

Toynbee, Arnold Joseph. Hellenism: The History of a Civilization. London: Oxford UP, 1960.

Van Wyk Smith, Malvern. The First Ethiopians: The Image of Africa and the Africans in the Early Mediterranean World. Johannesburg: U of the Witwatersrand P, 2009.

Vasunia, Phiroze. "Greater Rome and Greater Britain." Classics and Colonialism. ED. Barbara Goff. London: Duckworth, 2005. 38-64.

Veyne, Paul. Did the Greeks Believe in Their Myths? An Essay on the Constitutive Imagination. Trans. Paula Wissing Chicago: U of Chicago P, 1988.

Walcott, Derek. Omeros. London: Faber, 1990. 
Whitaker, Richard. Introduction. The Iliad of Homer: A Southern African Translation. Cape Town: New Voices, 2012. 11-59. 